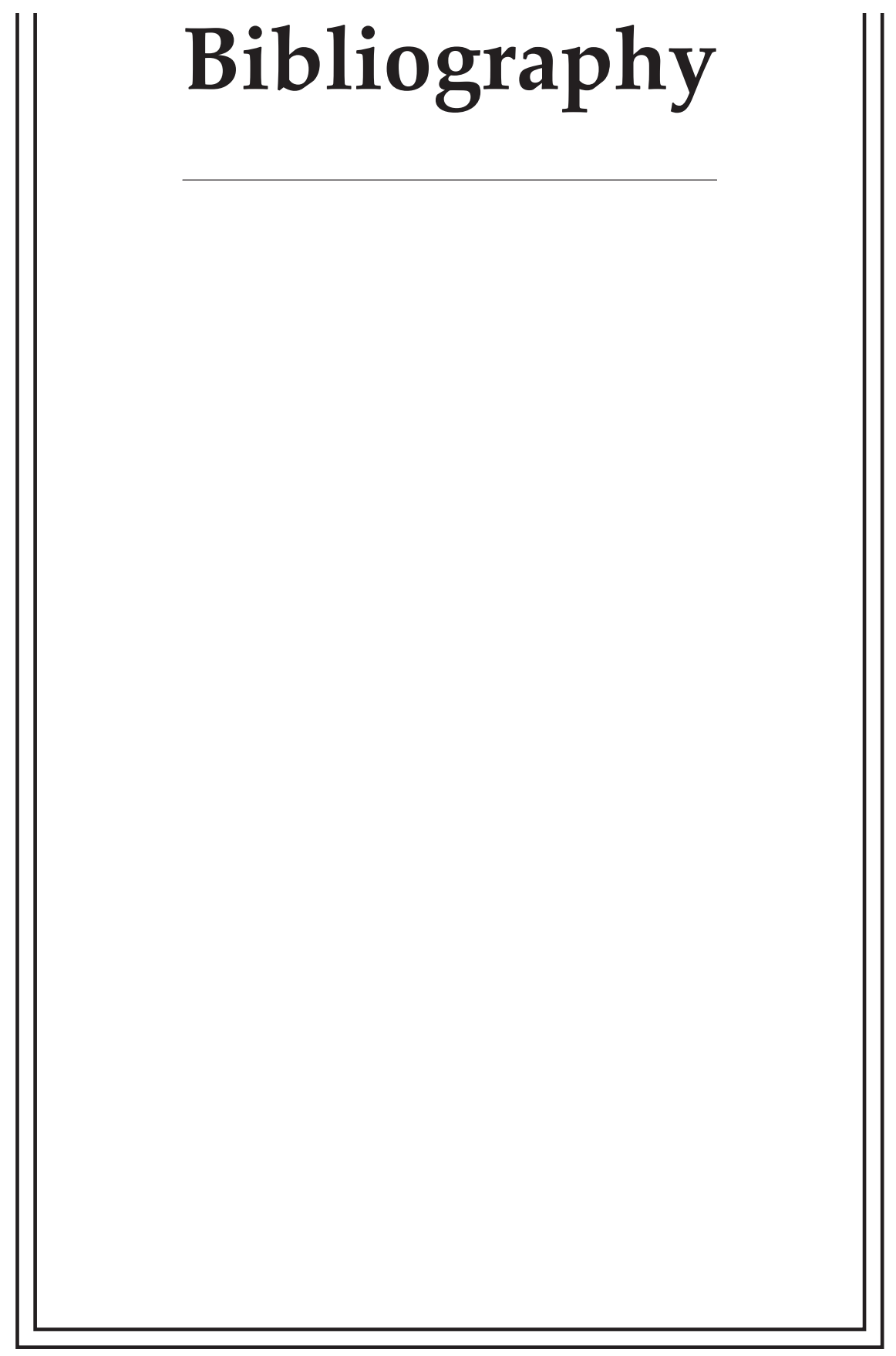


Roman Krivko

Moscow

roman.krivko@gmail.com

\section{NOTES ON THE DESCRIPTION OF THE OFFICE MENAIA IN THE “CATALOGUE OF GREEK MEDIEVAL AND RENAISSANCE MANUSCRIPTS IN THE COLLECTIONS OF THE UNITED STATES OF AMERICA"}

N. Kavrus-Hoffmann, Catalogue of Greek Medieval and Renaissance Manuscripts in the Collections of the United States of America. Part I: Culumbia University, Rare Book and Manuscript Library, Manuscripta 49 (2005) 165-245; Part II: The New York Public Library, Manuscripta 50 (2006) 21-76; Part III: Miscellaneous Small Collections of New York City, Manuscripta 51.1 (2007) 61-130; Part IV.1: The Morgan Library and Museum, Manuscripta 52.1 (2008) 65-174; Part IV.2, Manuscripta 52.2 (2008) 207-324; Part V.1: Harvard University, The Houghton Library, Manuscripta 54.1 (2010) 64-139;

Part V.2, Manuscripta 54.2 (2010) 207-274.

The catalogue by Nadezhda Kavrus-Hoffmann "aims at describing with modern criteria all the known Greek manuscripts in the United States." ${ }^{1}$ The goal of these notes is not to review the catalogue nor to analyze this work which is published in one of the world leading journals dedicated to the manuscripts studies, and which has already deserved to be held in high esteem by the prominent scholars: "Достаточно сказать, что описание отличается подным охватом особенностей манускриптов и является четким и детальным."2 Cataldi Palau informs that " $<\mathrm{a}>$ two-lines description of the codex is followed by a detailed description of the Contents; transcriptions from the manuscripts, incipit, explicit, lacunae, are written as they appear in the codex, with the exception of capital letters, following today's tendency in favour of a greater respect of the text as it appears in the manuscript.

(1) A. Cataldi Palau, [Review], in: E. Dobrynina (ed.), Chrysograph, vol. 3: Medieval book centres: local traditions and inter-regional connections (Moscow: Scanrus, 2009) 538.

(2) Б. А. Фонкич, [Review], in: E. Dobrynina (ed.), Chrysograph, vol. 3, 540. 
$<\ldots>$ The Bibliography, which follows and ends the description of each manuscript, is rich and detailed. The A.<uthor $>$ does not limit herself to the basic information, but discusses every relevant book she mentions, pointing out the main points of interest." ${ }^{3}$

The present notes are dedicated to the principals of the description of office Menaia. As is known, numerous catalogues of Byzantine manuscripts usually provide readers with standard, though by all means helpful, paleographical information, and sometimes even with remarks concerning deviations from the modern liturgical usage as represented by Roman or Venetian editions, but report nothing or almost nothing about a structure and content of the manuscripts. ${ }^{4}$ The tradition of the superficial description of Byzantine office Menaia ceased in the paradigmatic and fundamental catalogues by Herbert Hunger, Christian Hannick, Otto Kresten, ${ }^{5}$ and Salvatore Lilla. ${ }^{6}$ Their standart description of the content of the office Menaion includes $a$ ) indication of a month(s), the feasts which are included in the book, b) comprehensive description of the calendar, $c$ ) incipita of the hymnographic kanons with proper references to their publications including indication of volumes and pages (the necessity of which seems obvious). Moreover, in the most recent catalogue by Dorothey Getov the structure of the office Menaion has also been described ${ }^{7}$ (towards the structure of office Menaia see Roman Krivko's article in the present volume). Unfortunately, none of these criteria has been taken into consideration in the "Catalogue of Greek Medieval and Renaissance Manuscripts in the Collections of the United States of America" (hereafter: the Catalogue) nor the most important and up-to-date indices and editions has been used to identify the contents of the office Menaia. ${ }^{8}$ The only hymno-

(3) Cataldi Palau, [Review], 538.

(4) For references at the catalogues see my article published in this volume.

(5) H. Hunger, O. Kresten, Katalog der griechischen Handschriften der Österreichischen Nationalbibliothek, Teil 3/1: Codices theologici 1-100 (Wien, 1976) (Museion N.F. 4, Bd. 1, T. 3,1).

(6) S. Lilla, Codices Vaticani graeci. Codices 2162-2254 (Vatican, 1985); IDEM, Codices Vaticani graeci. Codices 2644-2663 (Vatican, 1996).

(7) D. Getov, A Catalogue of Greek Liturgical Manuscripts in the "Ivan Dujčev Centre for Slavo-Byzantine Studies" (Roma, 2007) (OCA, 279).

(8) Most relevant references chronologically ordered: H. FolLIERI, Initia hymnorum Ecclesiae Gracae, vol. I-V (1/2) (Città del Vaticano, 1960-1966) (Studi e testi, 211-215bis); E. Follieri, The "Initia Hymnorum Ecclesiae Graecae" - Bi- 
graphic publications, which have been considered in the Catalogue, are Roman Menaia (hereafter: MR I-VI) ${ }^{9}$ and on-line resource "analogion.gr" containing Greek liturgical books of modern rite published in htm- and pdf-format.

The present notes are based on the first four parts of the Catalogue which I could overview, because the most recent issues of the journal "Manuscripta" which appeared in 2010 (54.1, pp. 64-151, and 54.2, pp. 207-274) and in 2011 (55.1, pp. 1-108) are anavailable to me.

Only five miscellanies containing offices for the fixed feasts of the ecclesiastical year have been described in the observed parts of the Catalogue. Such an insignificant number of hymnographic books is typical for non historical collections of private origin, by which Greek manuscript heritage is represented in the public libraries of the USA. The highest level of the precious paleographical analysis of the sources which was done by Nadezhda Kavrus-Hoffmann makes it hardly possible for readers to realize the reason of out-of-date way of contents description of hymnographic miscellanies. However, the information provided by the Catalogue may help to gain some additional knowledge regarding the contents of the sources.

\section{New York University, Fales Library and Special Collections, possesses two disbound hymnographic fragments.}

1.1 “Box 1, no. 114. Menaion (?), fragment, s.xiii ${ }^{\mathrm{ex}} .<\ldots>$ contents $<\ldots>$

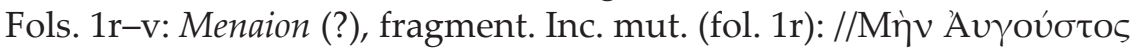

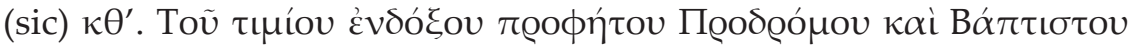

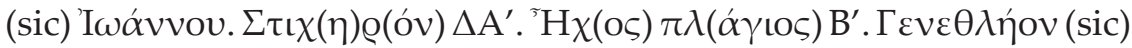

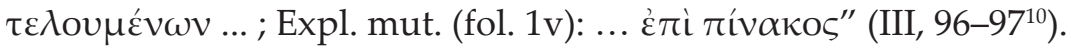

bliographical Supplement, in: E. Wellesz, M. Velimirovič (ed.), Studies in Eastern Chant, vol. II (1971) 35-50; AHG; Е. ПАПАНАIООҮ

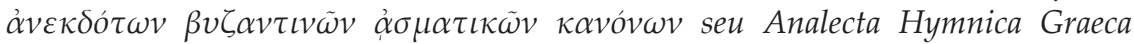

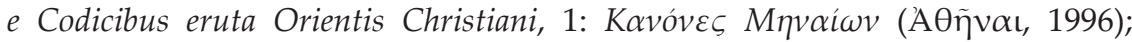
P. Plank, C. Lutzka, Das byzantinische Eigengut der neuzeitlichen slavischen Menäen und seine griechischen Originale, I-III Teilbände, hrsg. von Ch. HaNNICK (Paderborn-München-Wien-Zürich: Ferdinand Schöningh, 2006) (Abhandlungen der Nordrheinwestfälischen Akademie der Wissenschaften, Bd. 112; Patristica Slavica, hrsg. von H. Roтнe, 12. Bd).

(9) M

(10) Hereafter "Roman" and "Arabic" numbers indicate the part of the Catalogue and the pages accordingly. 
In this case the question mark is unnecessary. In the 13th c. a sticheron dedicated to a feast of the fixed ecclesiastical year could be placed either in the Menaion or in the Sticherarion. ${ }^{11}$ Since musical notation is absent from the manuscript, and Sticheraria without musical notation did never exist, the fragment MS no. 114 is a part of a festal Menaion or a daily Menaion for August. No information about the publication of the sticheron dedicated to the Beheading of John the Baptist (August 29)

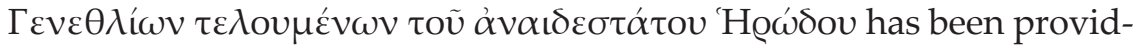
ed in the Catalogue, although it was published several times according to the well known Index by Enrica Follieri. ${ }^{12}$ (Hereafter all the incipita observed in Follieri's Index are not mentioned in the footnotes.)

1.2. “Box 1, no. 115. Menaion (?), fragment s.xiii (?) < ..> contents $<\ldots>$ Fols. 1r-v: Menaion (?), fragment. Inc. mut. (fol. 1r): // $\sigma \omega \theta \tilde{\eta} v \alpha \mathrm{t}$

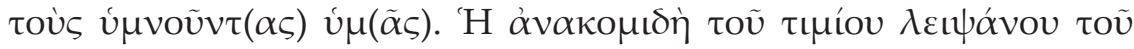

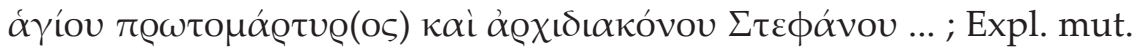

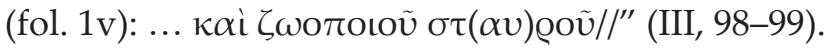

The fragment is a part of a Menaion for August or a festal Menaion (see the arguments above), the question mark is unnecessary. The month is defined according to the feast mentioned in the Catalogue, that is the Translation of relics of protomartyr Stephanos ( $\mathrm{H}$

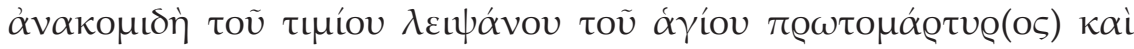

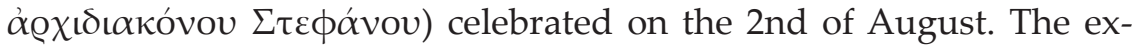
plicit $\kappa \alpha \grave{\zeta} \zeta \omega$ o $\pi$ oเov $\sigma \tau(\alpha v) \varrho o \tilde{v}$ may be related to the Procession of the Most Reverant Wood of the Life-Giving Cross celebrated on the 1st of August, which makes it possible to doubt that the archival indication of "recto" and "verso" sides of the folio is correct, cf.: "Only thirteen lines of the text remain" (III, 98).

1.3. "[S.n.]. Menaion, beginning missing $<\ldots>\mathrm{s} . \mathrm{xv}^{2 / 4}<\ldots>$ contents $<\ldots>$ Fols. 1r-414v: Menaion. No title $<\ldots>$. Inc. mut. (fol. 1r):

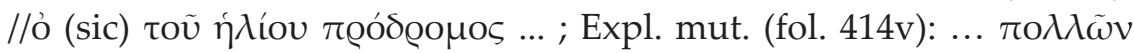
бoṽ $\theta \alpha v \mu \alpha ́ \tau \omega v / / "$ (III, 104). The manuscript begins with the office Menaion for January and probably contains the complete Menaion for this

(11) On "repertorium" of liturgical books in Byzantium and the most relevant editions and studies see the overview: Ch. HANnICK, Die byzantinischen liturgischen Handschriften, in: A. von Euw, P. SchreIner (Hrsg.), Kaiserin Theophanu. Begegnung des Ostens und Westens um die Wende des ersten Jahrtausends. Gedenkschrift des Kölner Schnütgen-Museums zum 1000. Todesjahr der Kaiserin, Bd. 2 (Köln: Schnütgen-Museum, 1991) 33-40.

(12) Follieri, Initia..., I, 246. 
month, or the festal Menaion for the whole or the first part of the ecclesiastical year. This is testified by the following evidences: the codex consisted originally of fifty-five quires, and the first one has been lost (III, 104). In the beginning of the second quire the end of the office for the 1st of January has been preserved (see below), which implies that the lost quire contained the beginning of the office for this day.

The incipit of the sticheron the text of which contains the words

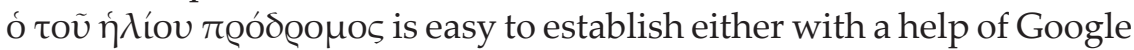
or the on-line resource <analogion.gr>, which contains liturgical books published in htm-format, so that the on-line search is technically possible by using one of the Greek Unicode fonts. The incipit of this stich-

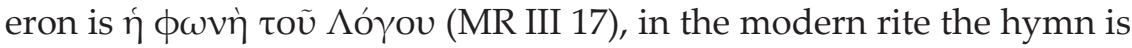
chanted as the katabasia on the 1st of January after the sixth ode of the kanon. The chant is the part of prefestal hymnography dedicated to the Theophany (6th of January).

The pictures of the folia $2 \mathrm{v}-3 \mathrm{r}$ of the manuscript has been published in the Catalogue. The fol. $2 \mathrm{v}$ contains the sticheron with the incipit

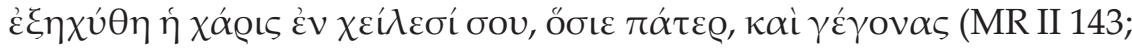
III 9, 12, 23). This is a so-called "general sticheron" dedicated to any saint bishop regardless of his name and personality. As in the Roman Menaion (MR III 9, 12, 23), the hymn is placed in the described manuscript at the commemoration of St. Basil the Great celebrated on the 1st of January. According to the marginal liturgical notes observed on the

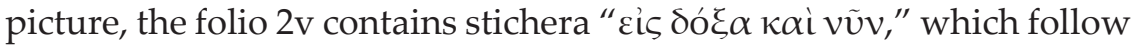

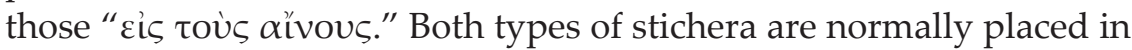
the younger Menaia at the end of the office according to their liturgical position. The date of the 1st of January is testified once again by the

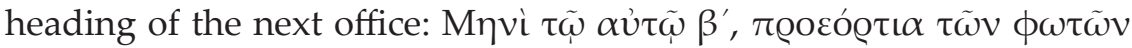

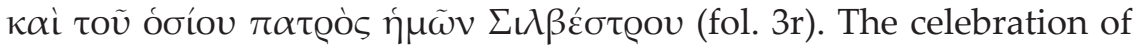
the Holy Lights ( $\tau \tilde{\omega} \nu \phi \omega \tau \tilde{\omega} v)$, or the Theophany, is prescribed on the 6th of January, and the commemoration of St. Silvester is celebrated on the 2nd of January. The fol. 3r contains usual festal and prefestal

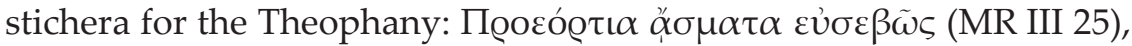

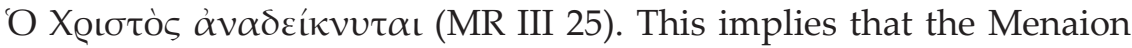
contains in the beginning (fol. 1r-3v) offices for the 1st (the commemoration of St. Basil the Great and the Prefest of the Theophany) and the 2nd of January (the commemoration of St. Silvester and the Prefest of the Theophany), so the lost first quire must have contained the beginning of the office for the 1st of January. To my opinion, this should have been reported in the catalogue. 
The attribution of the text containing the words " $\pi \mathrm{o} \lambda \lambda \tilde{\omega} \nu$ oov $\theta \alpha v \mu \alpha \dot{\tau} \omega v^{\prime \prime}$ indicated as the page explicit is hardly possible. For example, these words are observed in the kontakion dedicated to St. Euthimios the Great, the commemoration of which is celebrated on the 20th of January (modern rite):

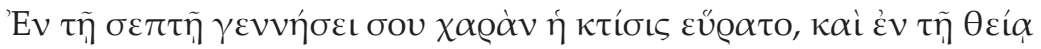

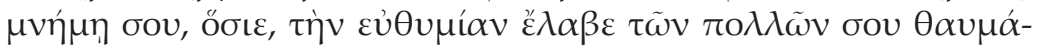

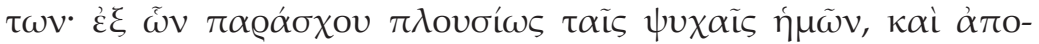

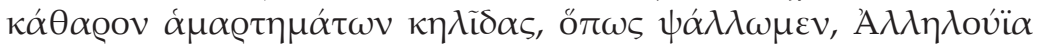
(http://analogion.gr/glt/texts/Jan/20.uni.htm).

However, Google makes it possible to reveal few more texts contain-

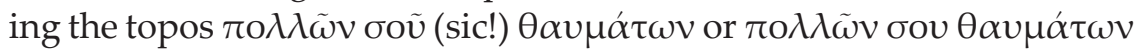
which finally provides user with no information regarding exact contents of the final part of the manuscript.

In the Catalogue the Roman Menaion is reported to contain the publication of the texts included in the manuscript: "Menaia tou holou eniautou, 6 vols. (Rome, 1888-1901)" (III, 104). The first and the second volumes of this edition cover the first three months of the ecclesiastical year (September-December), and the manuscript begins with the celebration of the 1st of January. If the bibliographic reference was correct, it would imply that the medieval manuscript covers the whole fixed calendar year according to the modern month count from January to December, which is very hard to believe. Moreover, the existence of the exact manuscript, which is assumed to be the source of the Roman Menaion, seems unbelievable, as this edition is based not on the manuscripts but on the previously published Venetian Menaia. ${ }^{13}$ I assume that no attribution of the texts included in the manuscript has been in fact performed by the author of the Catalogue.

\section{Union Theological Seminary Burke Library.}

"MS 41 Menaion, fragments <..> s.xiii ${ }^{\text {ex }}-$ s.xiv ${ }^{\text {in }}<\ldots>$ contents $<\ldots>$ Fols. 1r-26v: Menaion, fragments. No title. Inc. mut. (fol. 1r): // ...

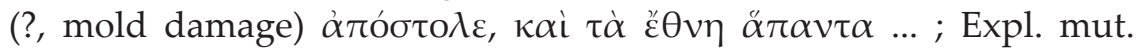

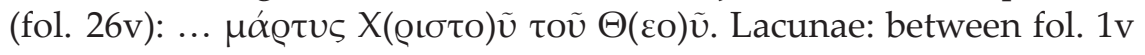

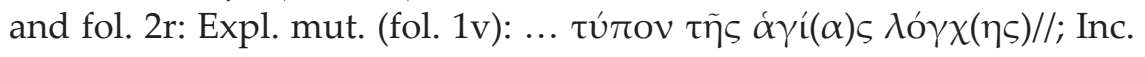

(13) On the Roman edition see: C. KorolevsKIJ, L'édition romaine des Ménées grecques 1888-1901 [I], Bolletino della Badia greca di Grottaferrata 3 (1949) 30-40, 153-162, 225-247; [II] Bolletino della Badia greca di Grottaferrata 4 (1950) 15-16. 


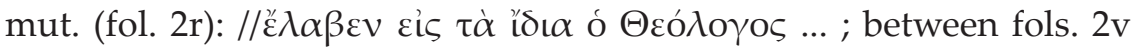

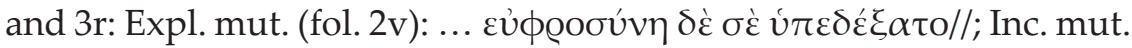

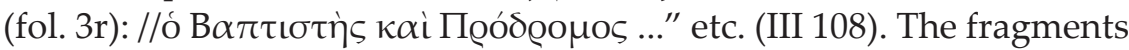
consist of "several incomplete quires" (III 109) written by one anonymous scribe (III 110). The description does not report a month nor provides a reader with precise information regarding the publication of the texts included in the manuscript. The description is followed by the same imprecise reference at the "Menaia tou holou eniautou, 6 vols. (Rome, 1888-1901)" (III, 109).

The fragments contain parts of the office Menaia for at least June and July. The offices for these months have been included in the 6th volume of the Roman Menaion, so this is not correct to consider all the six volumes of this edition to be the printed counterparts of the codex. The manuscript contains the commemorations of St. Onuphrios (12th of

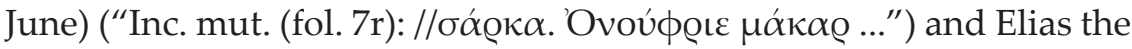

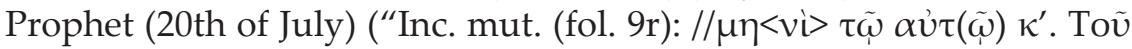

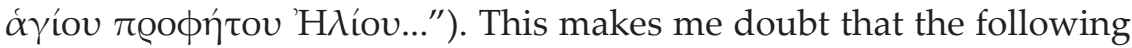
abbreviation has been deciphered correctly, concidering possible damage of fragments (cf.: "Some folios are darkened by exposure; some edges are torn; top margins are damaged by purple mold" (III, 109)):

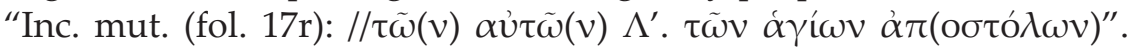
The commemoration of the 30 apostles (why thirty?!) does not exist in the ecclesiastical calendar, thereby I would suggest to read the letters

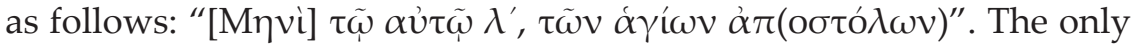
thirtieth day of a month on which the commemoration of more than one apostle is celebrated, is the 30th of June, when the Synaxis of the Holy Twelve Apostles is prescribed. However, the way I propose to read the heading makes me doubt if the archival foliation is correct: the commemoration of Elias the Prophert on 20th of July is attested on the fol. 9r, while the office on the 30th of June is placed on the fol. $17 \mathrm{r}$. The foliation made by employees of the library must be reconsidered

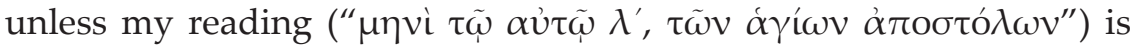
proven to be wrong.

\section{The Morgan Library and Museum.}

"MS M.35020. Anastasimatarion and Anthology, with late Byzantine notation $<\ldots>$ s.xviex - s.xvii ${ }^{1 / 4}$. <.. > contents $<\ldots>$ Fols. 1 r-v: blank. 1 .

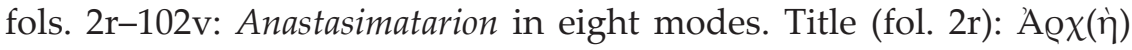

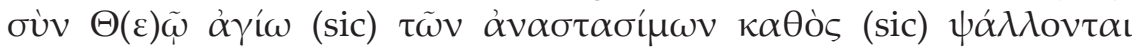

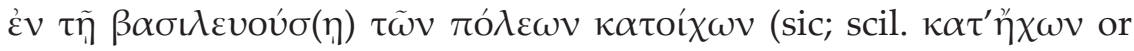


$\kappa \alpha \tau^{\prime}$ " $\left.\chi 0 v\right)$ " etc. "2. fols. 104r-204v: Anthology of troparia, antiphona, stichera, and hirmoi for the great feasts such as Christmas and Good

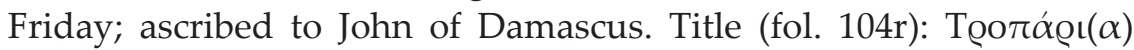

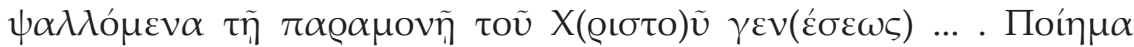

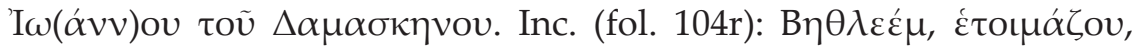

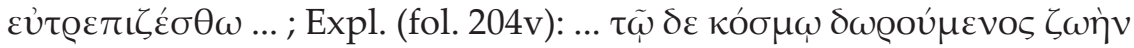

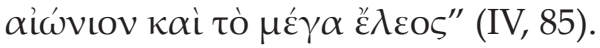

The author reports that " $<\mathrm{t}>\mathrm{exts}$ can be found at http://analogion. net/glt" (IV, 86, f. 21) while in the previous cases the reference at the Roman Menaion has been provided. The website "http://analogion.net/ glt" contains dozens of full text versions of Greek liturgical books, so reader should carefuly examine the resource by himself in order to identify the text he needs. It could have been mentioned in the Cat-

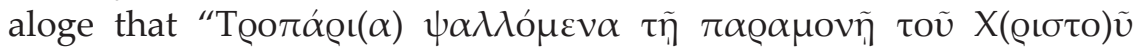

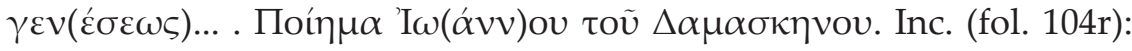

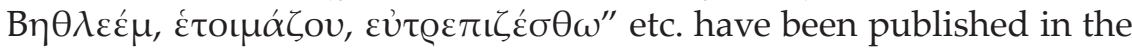
Roman Menaion (MR II 633) and reported by Enrica Follieri. However,

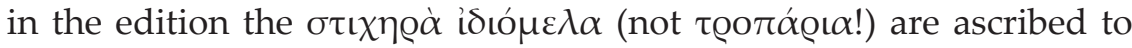
Sophronios the Patriarch of Jerusalem, thereby the attribution of the chants should have been critically discussed in the Catalogue.

These notes are by no means intended to doubt the final assessment of the Catalogue done by one of the recent reviewers: "Nadezhda Kavrus-Hoffmann has analyzed these manuscripts with ability and precision, providing researchers with an extremely useful scientific tool, set out with great typographic clarity and accuracy."14

(14) Cataldi Palau, [Review], 539. 